\title{
Application of computer-aided tomography to visualize and quantify biogenic structures in marine sediments
}

\author{
Rutger Rosenberg ${ }^{1, *}$, Earl Davey ${ }^{2}$, Jonas Gunnarsson ${ }^{3}$, Karl Norling ${ }^{1}$, \\ Michael Frank ${ }^{4}$ \\ ${ }^{1}$ Department of Marine Ecology, Göteborg University, Kristineberg Marine Research Station, 45034 Fiskebäckskil, Sweden \\ ${ }^{2}$ US Environmental Protection Agency, 27 Tarzwell Drive, Narragansett, Rhode Island 02882, USA \\ ${ }^{3}$ Department of Systems Ecology, Stockholm University, 10691 Stockholm, Sweden \\ ${ }^{4}$ Lysekil Hospital, Box 203, 45325 Lysekil, Sweden
}

\begin{abstract}
We used computer-aided tomography (CT) for 3D visualization and 2D analysis of marine sediment cores from 3 stations (at 10, 75 and $118 \mathrm{~m}$ depths) with different environmental impact. Biogenic structures such as tubes and burrows were quantified and compared among stations. Subsequent to CT scanning, the animals and other material in the cores were collected to validate the image analysis. The shallowest $(10 \mathrm{~m})$ station was the most anthropogenically impacted, having horizontally stratified sediment with few biogenic structures close to the sediment surface but many shells and relic tubes (i.e. tubes with no connection to the sediment-water interface) deeper in the sediment. The sediment at the reference station $(75 \mathrm{~m})$ and the deepest station $(118 \mathrm{~m}$, previously impacted by hypoxia) had large numbers of polychaete tubes throughout the sediment down to at least $30 \mathrm{~cm}$, although many of the tubes deeper down in the sediment were considered relic tubes. Inhabited tubes had a similar density to shells and seem to persist in the sediment for many years. Water volume of inhabited tubes was largest close to the sediment-water interface, whereas water volume in relic tubes was greater between depths of about $3 \mathrm{~cm}$ to $30 \mathrm{~cm}$. Many bivalves, particularly Thyasira equalis, were distributed in the middle and deep part of the sediment at the 75 and $118 \mathrm{~m}$ stations. Water volume of inhabited tubes was greatest at the $118 \mathrm{~m}$ station, showing that benthic fauna recovering from previous hypoxic events can establish burrows and tubes with greater volumes, and probably with greater impact on biogeochemical processes, than at a reference station with more stable environmental conditions. This investigation demonstrated that utilization of CT scanning and software can be applied to visualize and quantify physical and biological structures within sediment thicknesses of several decimetres.
\end{abstract}

KEY WORDS: Image analysis · Sediment · Bioturbation · Bioirrigation · Relic tubes · Burrows Resale or republication not permitted without written consent of the publisher

\section{INTRODUCTION}

About two-thirds of the Earth's surface is covered with soft marine sediments inhabited by benthic invertebrates. Although these animals are mainly located in the upper decimetres of the sediment, detailed information about their tube and burrow architecture, and their activity pattern is still fragmentary. Sediment-dwelling invertebrates are important as food for demersal fish, and their bioturbation and bioirrigation activities are crucial for sediment redox conditions and biogeochem- ical processes (Forster 1996, Furukawa et al. 2001, Riisgård \& Larsen 2005). Infaunal species have a major impact on the sediment properties and neighbouring species through their activity pattern and feeding mode (Grémare et al. 2004). For simplicity, benthic species can be assigned to different functional groups based on their mobility and where and how they feed (Pearson \& Rosenberg 1987, Pearson 2001), or to their sediment reworking activity pattern (François et al. 2002). The functional group concept is useful for investigations of the ecological role(s) of infaunal species. Several recent 
studies have investigated the functional roles of benthic invertebrates in sediment reworking (Josefson et al. 2002, Gerino et al. 2003, Solan et al. 2004, MermillodBlondin et al. 2005), mineralization and recycling of nutrients (Emmerson et al. 2001, Karlson et al. 2005, Mermillod-Blondin et al. 2005), and how these are linked to bacterial activity mediated by the infauna (Mermillod-Blondin et al. 2004). A functional biodiversity, e.g. the impact of the function of different species on nutrient fluxes, is not necessarily connected to an additive response, but rather the presence of multispecies functions can suppress the functions or activities of single species (Mermillod-Blondin et al. 2005).

Understanding the animal activity and functional response within natural and undisturbed sediment is hampered because the structural organization of the infauna is not visible and therefore not known. Only the edge of a sediment matrix, close to either the surface or the transparent wall of a core or aquarium, gives some information about possible infaunal structures. By using sediment profile imagery (SPI), it is possible to obtain useful 2D in situ information about redox conditions and biogenic structures, which mirrors the successional stages of the benthic communities (Rhoads \& Germano 1986, Rosenberg et al. 2002). The use of X-radiography for analysing the architecture of animal burrows in cores or thin aquaria allows observation of structures within the sediment (Schaffner et al. 2001). Bacterial (Thioploca) microstructures of surface sediments have been digitized and constructed as 3D images after scanning thin sections of a sediment sample (Fossing et al. 1995, Schulz et al. 1996). Perez et al. (1999) were pioneers in using computer-aided tomography (CT) for the study of biogenic structures in marine sediment. This nondestructive technique has more recently been used in studies in Canada for estimating the space occupied in the sediment by benthic fauna (Mermillod-Blondin et al. 2003, Michaud et al. 2003, Dufour et al. 2005).

The aim of the present study was to utilize CT and various image analysis techniques to visualize and quantify the distribution pattern of biogenic structures at 3 benthic stations with different environmental conditions; a reference station at $75 \mathrm{~m}$ depth (Stn 75), a station at $118 \mathrm{~m}$ depth (Stn 118) previously disturbed by low oxygen conditions, and a station at $10 \mathrm{~m}$ depth (Stn 10) with a long-term general disturbance of low oxygen concentrations. In addition, previous in situ documentation by the SPI technique revealed that large tube-building worms (Melinna cristata) had died during a hypoxic event in 1997 at Stn 118 (Nilsson \& Rosenberg 2000). Thus, a second aim of this study was to analyze the presence of relic tubes (i.e. tubes with no connection to the sediment-water interface, SWI) in the sediment, and whether these tubes persisted despite re-colonisation of the sediment by other bioturbating animals.

\section{MATERIALS AND METHODS}

Field sampling. Three stations on the Swedish Skagerrak coast, differing in depth and exposure to periodic hypoxic events, were sampled on 26 August 2004. Stn 75 was located in the Gullmarsfjord $\left(58^{\circ} 22.7^{\prime} \mathrm{N}\right.$, $\left.11^{\circ} 36.6^{\prime} \mathrm{E}\right)$; its faunal composition has remained similar for a long time and has not been significantly disturbed during hypoxic events (Rosenberg et al. 2002). Hence, this site was treated as an undisturbed reference station in this study. Stn 118 was located in the deepest part of the Gullmarsfjord $\left(58^{\circ} 19.4^{\prime} \mathrm{N}\right.$, $\left.11^{\circ} 32.7^{\prime} \mathrm{E}\right)$. Declining oxygen concentrations eliminated the benthic fauna from this station during 1997 (Nilsson \& Rosenberg 2000); however, the fauna had almost recovered to pre-hypoxic conditions in 2000 (Rosenberg et al. 2002). Stn 10 was located in the semi-enclosed Koljöfjord ( $\left.58^{\circ} 15.5^{\prime} \mathrm{N}, 11^{\circ} 34.1^{\prime} \mathrm{E}\right)$, near the Gullmarsfjord. The Koljöfjord is experiencing irregular but at least annual periods of hypoxia/anoxia that keep the benthic faunal communities in shallower bottoms in an early successional stage (deeper bottoms are often azoic) (Rosenberg et al. 2001). The oxygen concentrations in the vicinity of Stn 10 were declining prior to sampling, and in June the oxygen concentration was $2.1 \mathrm{ml} \mathrm{l}^{-1}$ at $15 \mathrm{~m}$ depth and below $1 \mathrm{ml} \mathrm{l}^{-1}$ at $20 \mathrm{~m}$.

Sediment and animal analysis. Sediment cores were collected with an Olausson box corer $(290 \times 290 \mathrm{~mm}$, $500 \mathrm{~mm}$ tall). On deck a PVC tube corer (340 mm long, $153 \mathrm{~mm}$ internal diameter, $5 \mathrm{~mm}$ thick wall) was inserted in the centre of each box core. A PVC tube corer was used since metals can interfere with $\mathrm{CT}$ imaging. A smaller tube corer $(\varnothing=5 \mathrm{~cm})$ was inserted into the box core (outside the PVC corer) for analysis of sediment geo-characteristics (porosity, grain size, C and N content). All sediment outside the tube corers was then removed and the top and bottom of the tube corer for CT analysis was sealed with PVC screw lids. All the cores were collected on the same day and transported by ship to Lysekil harbour. At the dock, the top lid of each core was removed and the overlying water was carefully siphoned off the sediment. One glass rod (6 $\mathrm{mm}$ ) and three $2 \mathrm{ml}$ plastic pipettes, one filled with seawater, the others with 30 and $50 \%$ Ludox $^{\circledR}$ (SigmaAldrich) were taped together and inserted into the sediment at the centre of each tube core until only their tops were visible at the SWI. The pipettes and rod were later used to calibrate the CT analysis for materials of different density, i.e. gas, water and rock or shell. Ludox is soluble in water and has a density close to silica. The ends of the pipettes were sealed with SiliconeII ${ }^{\circledR}$ (GE Sealants \& Adhesives). Before closing the tube cores, the capping technique from Michaud et al. (2002) was used to stabilize the sediment cores and 
prevent resuspension during transport to Lysekil hospital, and allowed them to be placed horizontally during scanning. Briefly, pieces of medical gauze were placed on the sediment surface and a 1:1 mixture of paraffin and Vaseline ${ }^{\circledR}$ (PV), heated to $\sim 60^{\circ} \mathrm{C}$, was poured onto the sediment to cover its surface with a layer $\sim 25 \mathrm{~mm}$ thick. A piece of polyurethane foam was then placed on top of the PV layer to fill out the rest of the empty tube core. This technique was used for 3 replicates from all 3 stations. For technical comparison, a fourth replicate sediment core was collected at Stn 75 in order to compare the PV technique with another capping method. In this other method the overlying water was removed and replaced by a viscous mixture of Cream of Rice ${ }^{\circledR}$ (Nabisco) and seawater to completely fill the space between the SWI and the top of the core.

The day after the CT scanning, the sediment of each core was sieved through a $1 \mathrm{~mm}$ mesh, and the animals were picked out live and photographed together with other objects. The location of the objects found within the CT images was compared with these photographs to verify and/or ground truth the quantity of living bivalves and tube worms compared to stones and unoccupied tubes and shells.

Total carbon (TC), total organic carbon (TOC) and total nitrogen $(\mathrm{TN})$ of the surface sediment (top $1 \mathrm{~cm}$ ) were analysed in 3 replicate samples from each station in a Carlo Elba elemental analyzer. Percent water and loss on ignition (LOI) were analyzed on sediment sliced into $1 \mathrm{~cm}$ sections every $5 \mathrm{~cm}$ down to $20 \mathrm{~cm}$. Sediment water content was analyzed after drying the sediment at $70^{\circ} \mathrm{C}$ to constant weight. LOI was determined after combustion at $500^{\circ} \mathrm{C}$ for $6 \mathrm{~h}$.

CT procedures. The original sediment CT procedures were described by Perez et al. (1999) and are summarized on a public access website (www.epa. gov/aed/html/ct/index.html). In general, during a CT scan, X-rays are altered as they penetrate objects of different densities. A digitized computer image (tomograph) is then created as a result of these alterations as the object is moved through the scanner. These densities are calibrated using a scale of Hounsfield units, which were previously re-defined as CT numbers (Perez et al. 1999). The CT numbers relate X-ray linear-attenuation coefficients to pixel brightness in a digitized image on a video monitor or film. Medical scanners are calibrated for air (CT number $=-1000$ ) and water $(\mathrm{CT}$ number $=0)$.

A 2D CT image is composed of pixels (a single area of equal length and width), each of which is associated with a specific CT number. Perez et al. (1999) defined and quantified, in 2D, the percentage of tube and burrow area and the sediment X-ray attenuation (SXA). A $3 \mathrm{D}$ image is composed of voxels (representing units of volume), which are pixels with a depth defined by the selected slice thickness. CT slice thickness is the uniform distance between sequential slices. All cores were CT scanned at Lysekil Hospital, Lysekil, Sweden, using a Siemens Sensation 4 medical scanner, at a slice thickness of $1.0 \mathrm{~mm}$, power settings of $120 \mathrm{kV}$ and $175 \mathrm{~mA}$, and a pitch of 1 . Since we used the same CT scanner and settings for all cores that were scanned in this investigation, the pixel resolution was $0.39 \mathrm{~mm} \times$ $0.39 \mathrm{~mm}$, the pixel area was $0.152 \mathrm{~mm}^{2}$ and the voxel volume was $0.152 \mathrm{~mm}^{3}$. The sediment cores were oriented horizontally (rotated $90^{\circ}$ from the vertical position as collected in the field, and scanned for between 90 and $120 \mathrm{~s}$ along their axis of uniform circular crosssections). All image data for each sediment core were stored on individual recordable compact discs (CD-R) in DICOM, a universal medical format.

The individual images of each core CD-R were transferred to a personal computer (Dell Latitude-Laptop model D800) using the software Osiris (Ligier et al. 1994), a freeware medical visualization program (available at www.sim.hcuge.ch/osiris/01_Osiris_Presentation_EN.htm). Osiris allowed 2D slices to be individually viewed and to quantitatively determine the CT number of any pixel or series of pixels within that 2D image. All core slice images from each core were saved as individual files from Osiris in DICOM. The individual files containing all the images of a core were then processed in the software program Alice (Parexel International, see www.perceptive.com/ products_imaging.html), which was also used for quantifying the data.

In Alice, to remove the container wall from the sediment images, a circular region of interest (ROI) within one slice of each core was defined and drawn around the sediment pixels to within 6 pixels of the container wall. The distance of 6 pixels was chosen because it is the distance over which the CT number changes between 2 different 'phases' of an image (i.e. wall from sediment, water from rock, sediment from gas). At distances less than 6 pixels, the 2 bordering phases are a composite of CT numbers of each. This ROI was then copied to all other slices of the core. The pixels outside these ROIs were assigned a CT number of 3000, which eliminated them from further analysis. Any sampling disturbances, which may have occurred along the core wall due to rocks or shells caught at the edge of the core container during coring, were also removed using this ROI definition process. These actions allowed $>90 \%$ of all the sediment data from each core to be used in further qualitative and quantitative procedures. After the wall of the core had been removed, a new 2D data set containing all the slices in one large file was created within Alice and transported to the software program T3-D (ITT Visual Information Solu- 
tions, see www.ittvis.com/noesys/index.asp). In T3-D, the image data could be selectively examined over any chosen CT range and the voxels comprising these ranges could be visually represented as a 3D image. The increased resolution obtained from horizontal scanning and 3D imaging allowed artefacts such as waterlogged plant materials and relic tubes to be located and separated from the 2D data set in Alice, prior to calculations.

The calibration tubes were used to estimate the CT number range of structures in the sediment. Gas within the cores was differentiated between the CT number ranges of -1000 to -1 . The lower range for physical water was set at zero and the upper range limit was determined from the mean CT number for water inside the $2 \mathrm{ml}$ pipette inserted in the core for each slice. The average SXA at each depth was calculated from 1 the upper range of water to CT number 700. Sand and dense biogenic tubes were estimated within the CT range of 701 to 1000 and rock and shell were estimated within the CT range of 1001 to $>2000$. Scans of objects containing multiple media generate distributions of CT numbers, rather than single values, because objects of different densities influence the $\mathrm{CT}$ number reading of adjacent objects. For example, water inside some dense faunal tubes within sediment has a CT number ranging from 0 to 350 rather than $\mathrm{CT}$ number $=0$. The number of voxels for each core component was plotted for each millimetre depth within each sediment core. The total was calculated as the sum of all voxels of the component, divided by the total number of voxels within the core, and expressed as a percentage. All data for each core was archived on CD-R.

A general water (GW) CT range of 0 to 100 was used to calculate the number of water voxels with depth. However, this calculation (as shown later in 'Results') could simultaneously under-estimate the living biotic activity within the surface layers of the sediment, and over-estimate it in deeper layers because there were so many broken and degraded relic tubes and abandoned burrows throughout the sediment. In addition, some gas bubbles produced by bacteria or perturbations during coring could appear to be coated with water.

Therefore, we developed techniques to distinguish living animals and/or their active burrows, tubes and shells from GW. Worm tubes connected to the SWI were counted as recent and inhabited tubes, whereas those tubes at deeper depths with no obvious connection to SWI were not included in this calculation. This would give a conservative estimate since, for some tubes, the connection to the SWI lay beyond the collection diameter of the sediment core and could not be observed. At all sediment depths, bivalves that contained water, i.e. tissue within their shells, were considered as living, and these voxels were counted. Since these fjord sediments contained numerous living tube worms and bivalves which had denser tubes or shells (CT number $>700$ ) than the surrounding sediment, it was possible to locate the voxels of these objects within the $2 \mathrm{D}$ images by their shapes, using a CT number range of 701 to $>2000$. Once located, the water within these objects could be determined and counted using a $\mathrm{CT}$ number range of 0 to 350 . The upper range for water within these objects could be extended beyond $\sim 100$ because in the distance of 6 pixels between the 2 phases (i.e. water and sediment or shell), half of the voxels belong to the water phase (i.e. the upper CT number range is extended from $\sim 100$ to $\sim 350$ ) and the other half belong to the sediment or shell phase (i.e. the lower CT number range is extended down to 2351 ). Consequently, in this investigation, biotic water (BW) will be defined as water voxels that were either located in organisms and/or structures that had an obvious connection to the SWI, as well as bivalves containing water found at greater depths within the sediment. We also visualized and calculated the tube and shell voxels (T\&S) surrounding BW and the total biovolume (BV = $\mathrm{BW}+\mathrm{T} \& \mathrm{~S})$.

Statistical analysis. For all tests, homogeneity of variances was tested by Cochran's-test. When homoscedasticity was not observed, data were square-root or fourth-root transformed to homogenize variances. Statistical analysis of differences in percent $\mathrm{C}$ and $\mathrm{N}$ between stations was made by 1-way ANOVA. If stations were significantly different, Student NewmanKeuls (SNK) post hoc tests were performed to determine which stations differed. Percent water and LOI were measured at different depths of the sediment and tested with a 1-way repeated measures analysis of variance (RM ANOVA) with station as the main effect and depth as a repeated factor (within subject) because depth and measurements were not independent. If stations were significantly different, SNK post hoc tests were used to determine the stations, depths and interactions that differed. Statistical analysis was preformed using Statistica 6.0 TM (StatSoft). RM ANOVA was used for analysing differences in the CT measurements.

\section{RESULTS}

\section{Sediment quality}

The percent TC, TOC and TN of the top $(0$ to $1 \mathrm{~cm})$ sediment indicate a carbon enrichment and nutritional gradient (increasing $\mathrm{C}: \mathrm{N}$ ratios) between stations of $10>75>118$ (Table 1). LOI was significantly different between Stns 10, 75 and 118 (RM ANOVA $F=48, \mathrm{p}<$ 0.05 ; Table 2). Similar to TOC, Stn 10 had the highest 
Table 1. Percent total organic carbon (TOC), total carbon (TC), total nitrogen (TN), and C:N in the sediment surface layer $(0$ to $1 \mathrm{~cm}$ ) from 3 stations in a Swedish fjord in August 2004. Values in parentheses are SD $(n=3)$. Station number: seawater depth $(\mathrm{m})$ at station

\begin{tabular}{|lcccr|}
\hline Stn & TOC & TC & TN & \multicolumn{1}{c|}{ C:N } \\
\hline 10 & $4.49(0.61)$ & $4.66(0.68)$ & $0.53(0.07)$ & $8.84(0.17)$ \\
75 & $2.85(0.06)$ & $3.57(0.03)$ & $0.32(0.01)$ & $11.18(0.21)$ \\
118 & $2.76(0.01)$ & $3.93(0.02)$ & $0.34(0.01)$ & $11.47(0.09)$ \\
\hline
\end{tabular}

Table 2. Percent water content $\left(\mathrm{H}_{2} \mathrm{O}\right)$ and loss on ignition (LOI) in sediment at $0-1,4-5,9-10,14-15$ and $19-20 \mathrm{~cm}$ depth in sediment core samples from 3 stations in a Swedish fjord in August 2004. Values in parentheses are SD $(\mathrm{n}=3)$. Station numbers as in Table 1

\begin{tabular}{|cccr|}
\hline Stn & $\begin{array}{c}\text { Sediment } \\
\text { depth }(\mathrm{cm})\end{array}$ & $\begin{array}{c}\text { Mean } \\
\mathrm{H}_{2} \mathrm{O}(\%)\end{array}$ & $\begin{array}{c}\text { Mean } \\
\text { LOI }(\%)\end{array}$ \\
\hline 10 & $0-1$ & $77.9(2.3)$ & $12.5(1.3)$ \\
& $4-5$ & $65.1(3.7)$ & $7.9(1.0)$ \\
& $9-10$ & $50.5(3.1)$ & $5.5(0.6)$ \\
& $14-15$ & $54.0(2.9)$ & $7.4(0.5)$ \\
75 & $19-20$ & $53.4(1.8)$ & $6.9(0.6)$ \\
& $0-1$ & $69.5(0.8)$ & $9.8(1.1)$ \\
& $4-5$ & $63.7(0.4)$ & $9.8(0.7)$ \\
& $9-10$ & $61.9(1.0)$ & $10.1(0.9)$ \\
118 & $14-15$ & $59.8(0.8)$ & $10.0(0.0)$ \\
& $19-20$ & $60.5(0.4)$ & $9.9(0.2)$ \\
& $0-1$ & $75.3(1.8)$ & $11.9(0.2)$ \\
& $4-5$ & $68.9(0.3)$ & $12.4(0.1)$ \\
& $9-10$ & $67.9(1.3)$ & $12.6(0.3)$ \\
& $14-15$ & $66.1(1.6)$ & $12.9(0.3)$ \\
& $19-20$ & $65.7(0.7)$ & $11.3(2.0)$ \\
\hline
\end{tabular}

Table 3. Number of live animals found in sediment core samples from 3 stations in a Swedish fjord in August 2004. Single records of a species are not reported. Station numbers as in Table 1

\begin{tabular}{|c|c|c|c|c|c|c|c|c|c|}
\hline \multirow[t]{2}{*}{ Species } & \multicolumn{9}{|c|}{ Station:core numbers } \\
\hline & $75: 1$ & $75: 2$ & $75: 3$ & $118: 1$ & $118: 2$ & $118: 3$ & $10: 1$ & $10: 2$ & $10: 3$ \\
\hline Eunucula tenuis & & & & 6 & & & & & \\
\hline Thyasira equalis & 3 & 1 & 1 & 6 & 6 & & & & \\
\hline Amphiura filiformis & 5 & 3 & 4 & & & & & & \\
\hline Amphiura chiajei & 1 & 2 & 1 & & & & & & \\
\hline Abra nitida & 5 & 5 & 3 & 1 & 1 & 1 & & & \\
\hline Maldane sarsi & 3 & 1 & & & & & & & \\
\hline Melinna cristata & 1 & 4 & 2 & 2 & & & & & \\
\hline Ampharete sp. & 1 & & & 2 & 1 & 2 & & & \\
\hline Scalibregma inflatum & & 1 & & & & 1 & & & \\
\hline Terebellidae & & 1 & & & 1 & & & & \\
\hline Euchone papillosa & & & & 5 & 2 & 1 & & & \\
\hline Polychaeta, indet & & & & 1 & 6 & & & & \\
\hline Capitella capitata & & & & 2 & 1 & & & & \\
\hline Anobothrus gracilis & & & & 2 & & 1 & & & \\
\hline Amphictes gunneri & & & & & & 3 & & & \\
\hline Amphitrite sp. & & & & & & 3 & & & \\
\hline Pectinaria koreni & & & & & & & 1 & 8 & 2 \\
\hline Abra alba & & & & & & & & 6 & \\
\hline Nereis diversicolor & & & & & & & & & 2 \\
\hline
\end{tabular}

percentages (and variances) of LOI in the surface ( 0 to $1 \mathrm{~cm}$ ) sediment. At depths $>1 \mathrm{~cm}$ in the sediment, Stn 10 had significantly lower values compared to Stns 75 and 118 (Table 2).

The percent water content of the sediment was significantly different between Stns 10, 75 and 118 (RM ANOVA, $F=31, \mathrm{p}<0.05$; Table 2). Post hoc comparisons of the top sediment $(0$ to $1 \mathrm{~cm}$ ) gave the following significant differences: $10>118>75$. Similar to the LOI, the water content dropped dramatically for deeper sediment layers at Stn 10.

\section{Benthic fauna}

The benthic species and their abundances found in the cores are listed in Table 3. Only 3 live species were found in the 3 cores at Stn 10, which distinguished this benthic community from those at the other stations. Most common among the species at Stn 75 were the brittle stars Amphiura filiformis and A. chiajei, the bivalve Abra nitida and the tube building polychaetes Melinna cristata and Maldane sarsi. Tubes inhabited by Melinna cristata may extend more than $10 \mathrm{~cm}$ down in the sediment. Common species at Stn 118 were the tube-worm Euchone papillosa (tube down to $10 \mathrm{~cm}$ in the sediment), and the bivalve Thyasira equalis (frequently found $>10 \mathrm{~cm}$ deep in the sediment). Some species were common at both Stns 75 and 118, but the brittle stars were only found at Stn 75. Black Pectinaria koreni tubes and empty shells were found as remnants, particularly of Eunucula tenuis, Thyasira equalis, Abra nitida and Nuculana pernula at Stns 75 and 118. We were unable to determine which of the empty worm tubes had been inhabited as some of the animals had left their tubes, probably during the sorting procedure.

\section{Sediment and biogenic structures analyzed by $\mathrm{CT}$}

The plot of the average over the mean SXA (CT number) in each replicate at a given sediment depth (Fig. 1) shows that the sediment bulk densities at all the stations were statistically (RM ANOVA, p < 0.01 ) different from one another. However, for Stn 10 the sequence changed with depth, from having the softest sediment at the SWI down to $\sim 40 \mathrm{~mm}$, to having the 


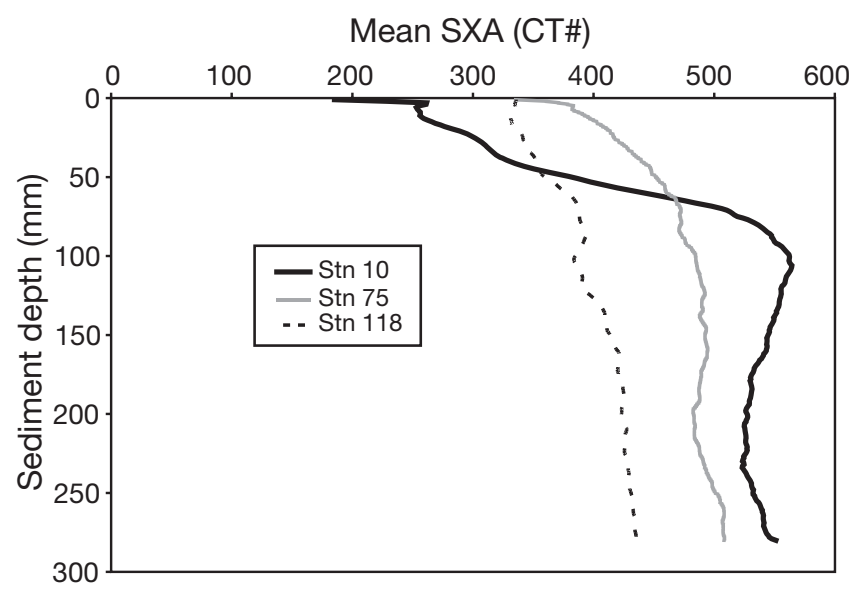

Fig. 1. Mean sediment X-ray attenuation $\left(\mathrm{SXA}_{\mathbf{i}} \mathrm{CT}\right.$ number range: 0 to 600$)$ with sediment depth for cores $(n=3)$ from 3 stations in a Swedish fjord in August 2004. Station number: seawater depth (m) at station; CT: computer-aided tomography densest sediment below $\sim 70 \mathrm{~mm}$. The sediment density with depth was comparatively more uniform at Stns 75 and 118, and the latter station had the softest sediment of the 3 stations below $\sim 40 \mathrm{~mm}$ depth.

Two techniques were used to stabilize the SWI before tilting the tube into the horizontal position for scanning (Fig. 2), as described in 'Materials and methods'. The paraffin-Vaseline on top of the gauze dislocated the worm tubes protruding above the sediment surface, which were pressed down or bent underneath the capping (Fig. 2B). It appears that the 'Cream of Rice' poured down between the tubes left their positions comparatively unchanged (Fig. 2A). It is not likely that either of the 2 capping techniques would have had any different and significant impact below the sediment surface.

Qualitative comparisons for gas, water, soft sediment and rock/shells between the 3 stations are shown in
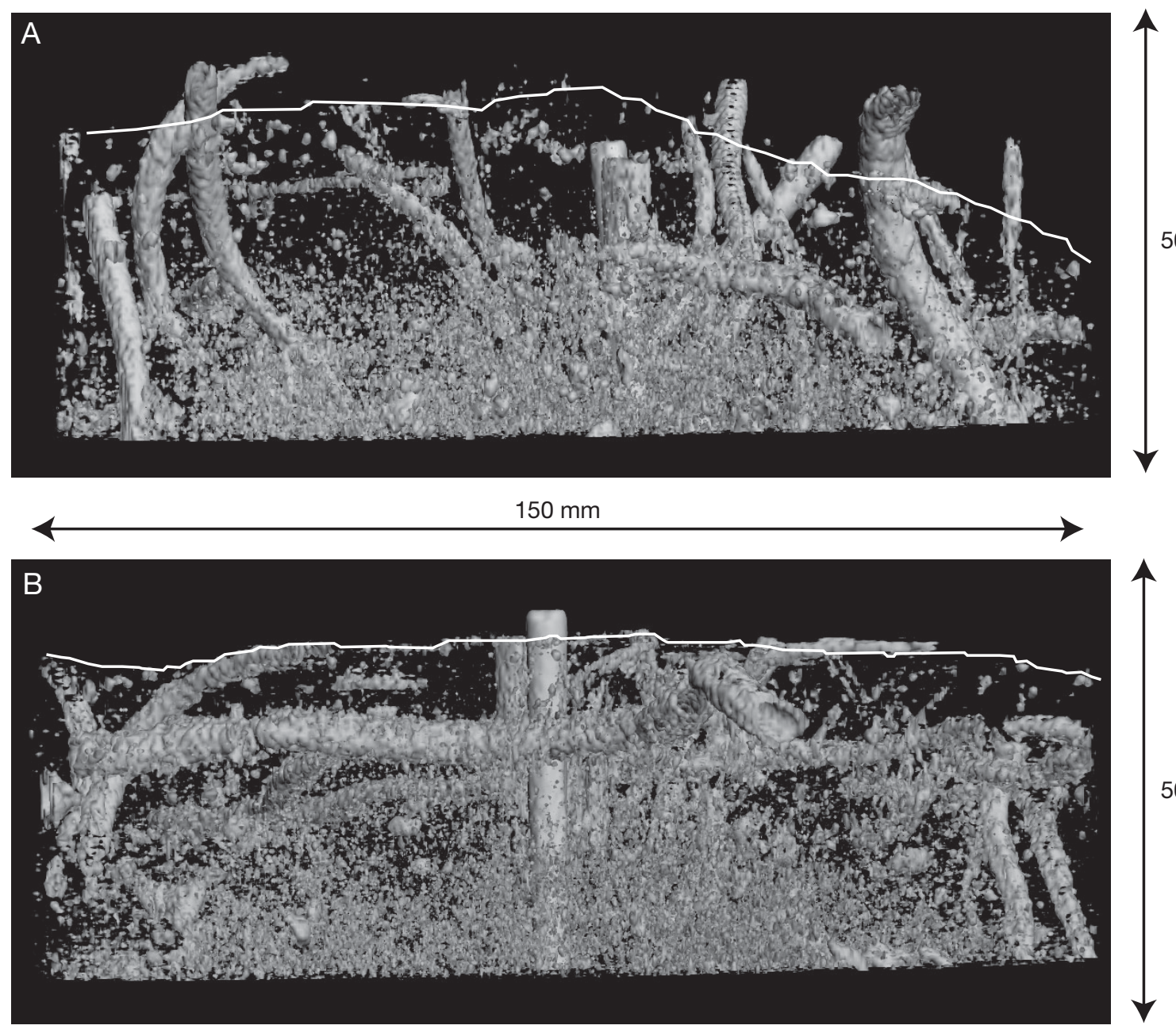

Fig. 2. 3D visualizations from CT scanning (CT number range: 500 to 1000) of polychaete tubes in sediment cores, where different capping methods have been used to keep the sediment-water interface (SWI) intact during horizontal scanning. Both cores were collected from Stn 75. (A) Capping with 'Cream of Rice'; (B) capping with paraffin and Vaseline (see 'Materials and methods' for details). White lines: approximate position of the SWI 
Fig. 3. The sediment at Stn 75 had slight air contamination, which probably occurred during the insertion of the calibration rod and pipettes. At this station most of the biotic water was located within $100 \mathrm{~mm}$ of the SWI. Some dense tubes occurred at greater depths without connection to the SWI. Some shells and rocks appeared towards the centre and bottom of the core. The sediment at Stn 118 contained some gas (air) towards the top of the core. At this station, many large dense tubes and relic tubes were found throughout all depths of the core, but few rocks and shells. The sediment at Stn 10 had a high gas content, especially in the lower third of the core (probably methane or nitrogen). Some shells in the top sediment were probably the bivalve Abra alba (Table 3), with large numbers of empty shells and pebbles deeper down. Relic tubes were found below approximately $100 \mathrm{~mm}$ depth at this station. The sediment at this station had the lowest
SXA of all stations from the SWI down to approximately 50 to $70 \mathrm{~mm}$, which is clearly visible in the image, particularly in contrast to Stn 75. Stn 118 had far more relic worm tubes than any other station. Relic tubes were also found in the deeper parts of the cores at Stns 75 and 10.

The sediment from Stn 118 contained numerous relic worm tubes filled with water (Fig. 4, left panel). The calibration pipette (straight object) filled with water was used to calibrate the CT number range of water, in this case 0 to $\sim 100$, with depth in the core. At the top of the left panel (Fig. 4) is the medical gauze saturated with water, which was used for stabilizing the sediment during scanning. After removal of the relic tubes and other extraneous water in the image analysis (Fig. 4, right panel), a picture is produced that shows only the water contained within animals close to the SWI, and animal tubes connect-
Rock
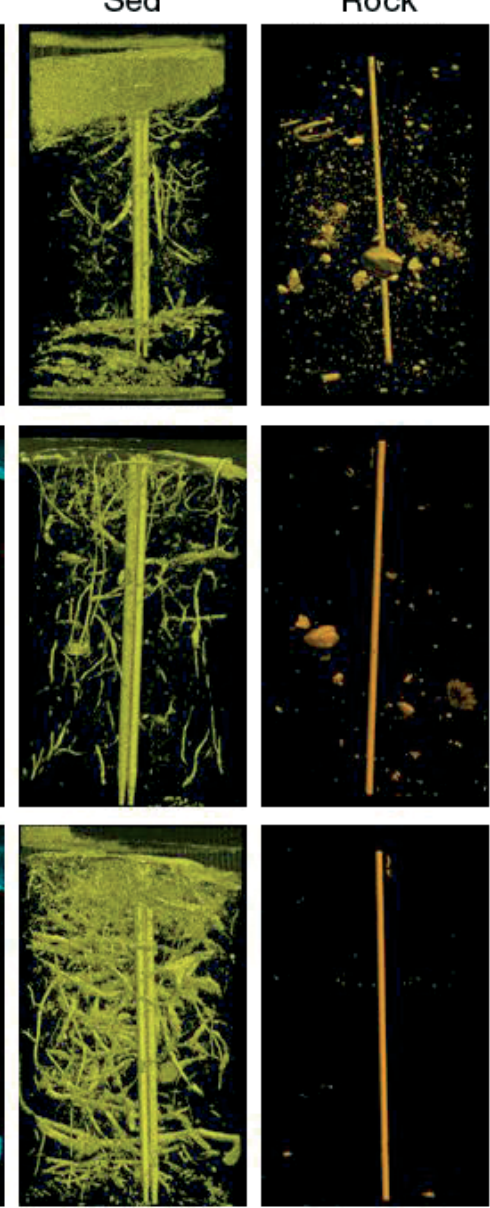

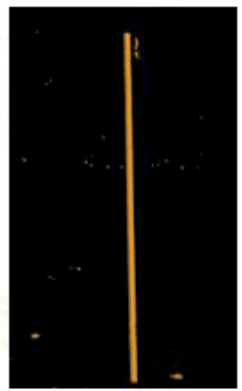

Fig. 3. 3D visualizations from CT scanning showing objects appearing at different CT number ranges in sediment cores from Stns 10, 75 and 118: gas (CT $=-1000$ to -1 ); water ( $\mathrm{CT}=0$ to 100 ) mainly in the worm tubes; sediment and worm tubes (sed; CT = 101 to 700$)$; and rock/shell (rock; CT = 701 to $>2000)$. The vertical rods were inserted for calibration of CT ranges (see 'Materials and methods'). Core length $\approx 30 \mathrm{~cm}$. Station numbers as in Fig. 1 depth are Thyasira equalis and Eunucula tenuis. Since the worm tubes surrounding the biotic water and the bivalve shells are dense (CT number $>700$ ), the biotic water within these structures could range from CT number 0 to 350. The volume of the biotic water was greater than the volume of water estimated in the relic tubes (general water) in the upper part of the sediment (Fig. 4). However, for the rest of the sediment, the estimated volume of relic water appeared to be much larger than the biotic water.

A comparison with image examples from each station of the general water (mainly in relic tubes), biotic water, and the biotic water including the tubes and/or shells surrounding the biotic water (biovolume) is shown in Fig. 5. Stn 10 only contained shells (Abra alba) close to the SWI. Both Stns 75 and 118 contained tube worms extending down to approximately $100 \mathrm{~mm}$, and bivalves from the SWI down to depths greater than $200 \mathrm{~mm}$. Some of the larger tubes at Stn 75 are likely to have been Melinna cristata, and most of the tubes at Stn 118 were Euchone papillosa. Notably, tubes and shells had a similar SXA indicating that they had a similar material density.

The relative volume of water within tubes and shells (number of voxels of 

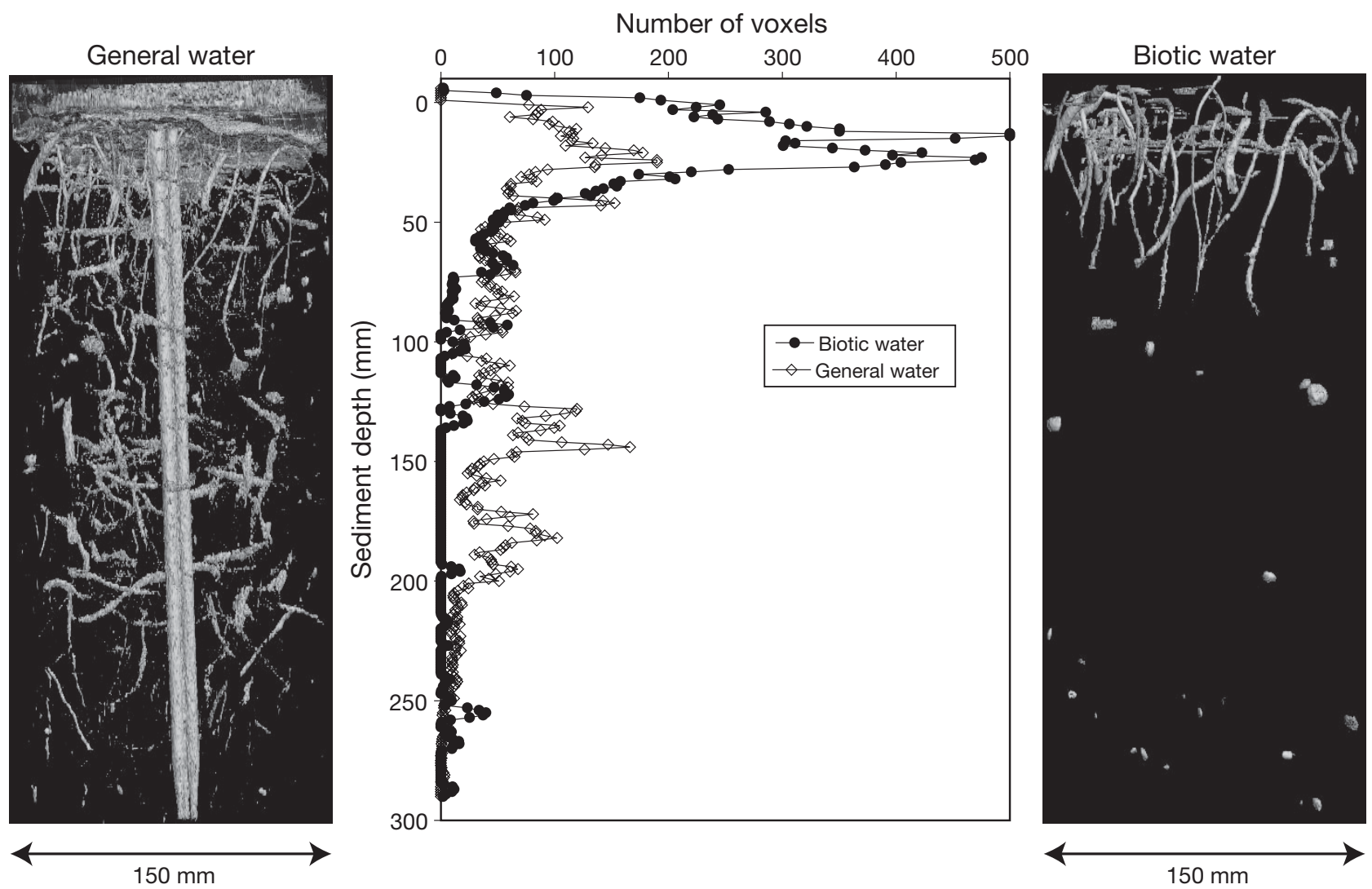

Fig. 4. 3D visualizations to show the difference between water predominantly in relic tubes (general water, GW; CT $=0$ to 100 ) and water in inhabited worm tubes and shells (biotic water, BW; CT $=0$ to 350) in a sediment core from Stn 118. Most of the relic tubes were from Melinna cristata. Number of voxels correlates to the water volume in the tubes. Core length $\approx 30 \mathrm{~cm}$. The vertical rods in the left panel were used for calibration of CT ranges

biotic water) vs. depth in the sediment (Fig. 6) shows the following significant statistical difference between stations: $118>75>10$. The greater number of tubes appearing towards the top of the sediment at Stn 118 compared to Stn 75 accounts for a greater volume. Biotic water is present at most depths all the way down to the bottom of the cores at Stns 75 and 118, whereas there appeared to be no biotic water below $25 \mathrm{~mm}$ at Stn 10.

\section{DISCUSSION}

\section{Sediment}

The sediment at all stations showed a significant decrease in water content as a function of depth in the sediment: however, the greatest decrease of interstitial water occurred at Stn 10, which coincided with a drop in LOI. Thus, the top sediment was very different from that below 4 to $5 \mathrm{~cm}$ depth. The sediment LOI at Stn 118 was constant with depth, and was higher than at Stn 75, indicating carbon enrichment by animal reworking. Carbon and TOC content of the surface sediment were highest at Stn 10, followed by Stn 118 and then Stn 75, which suggested either more recent carbon input at Stn 10 and/or less carbon utilization compared to Stns 75 or 118 . The lower C:N ratio at Stn 10 also suggested that the input is not being utilized as much as at Stns 75 and 118, or that the input of organic matter is different. These results clearly show that Stn 10 (the most disturbed station) is different from Stns 75 and 118 .

In the CT images, the sediment at Stn 10 had the lowest SXA of all stations from the SWI down to approximately $50 \mathrm{~mm}$ (Fig. 1); however, below about $70 \mathrm{~mm}$ the SXA at Stn 10 was higher than at the other stations (Fig. 1). The plots of average mean SXA (CT\#) with depth mirrored that of percent water and LOI, showing that all stations were statistically different. Thus, it is evident that the CT technique can provide detailed information about the sediment properties related to density, and that this analysis can be done fairly rapidly with a high resolution. 


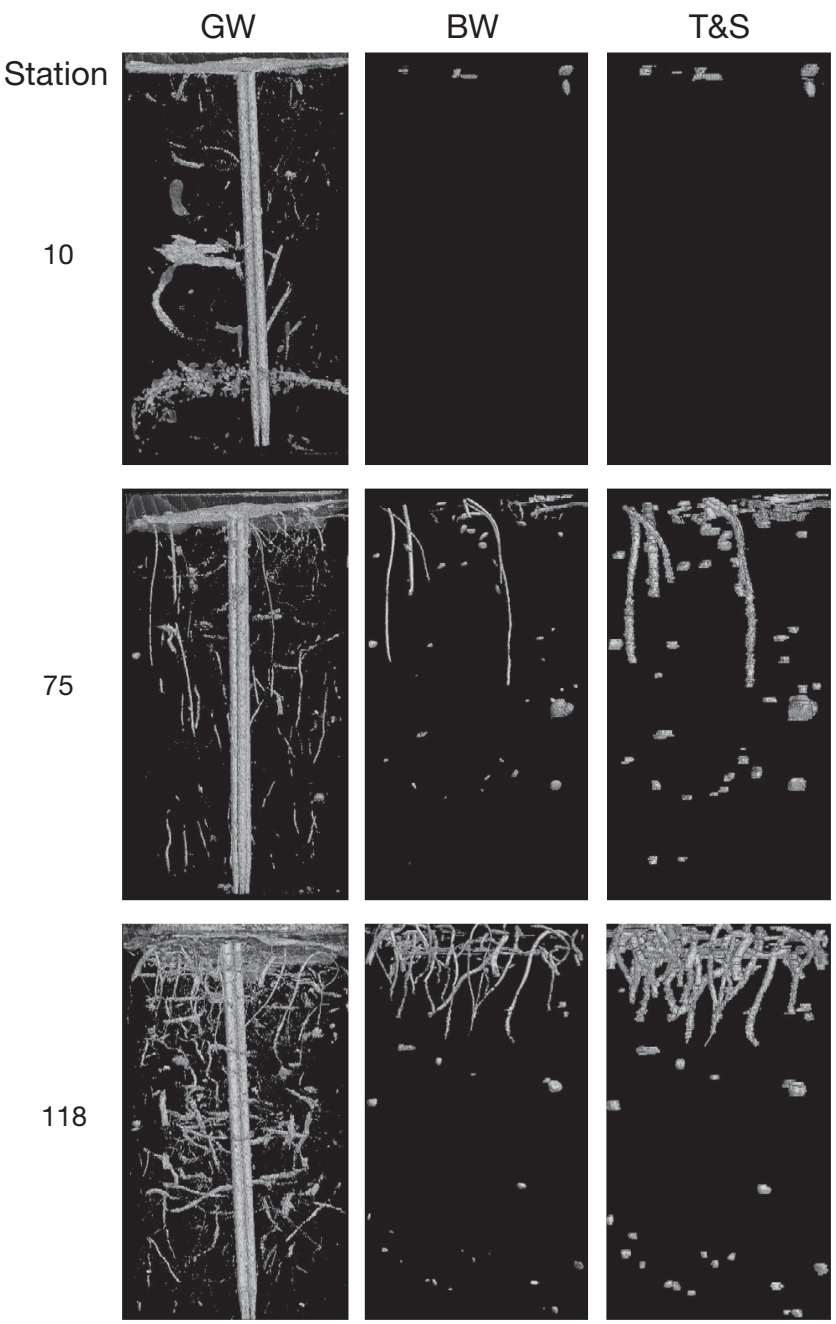

Fig. 5. 3D visualizations of water predominantly in relic tubes (general water, GW; CT $=0$ to 100), water inside inhabited tubes and shells (biotic water, $\mathrm{BW} ; \mathrm{CT}=0$ to 350 ), and structures surrounding the biotic water (tubes and shells, T\&S; $\mathrm{CT}=351$ to 2000) in sediment cores from Stns 10, 75 and 118 . The vertical rods in the left column were used for calibration of CT ranges. Station numbers as in Fig. 1

\section{CT techniques}

A comparison of the 2 techniques used to stabilize the SWI before CT scanning the sediment cores in horizontal position showed that the Cream of Rice (CR) technique was easier to apply than the PV method by Michaud et al. (2003). The PV method both compressed and dislocated the worm tube structures protruding through the sediment-water interface (Fig. 2). The application of the hot PV may kill or disturb the benthic biota. However, in the present study it is probable that no animals were killed, as only live animals were sorted from the sediment. For detail studies of biogenic structures above the SWI, when cores are

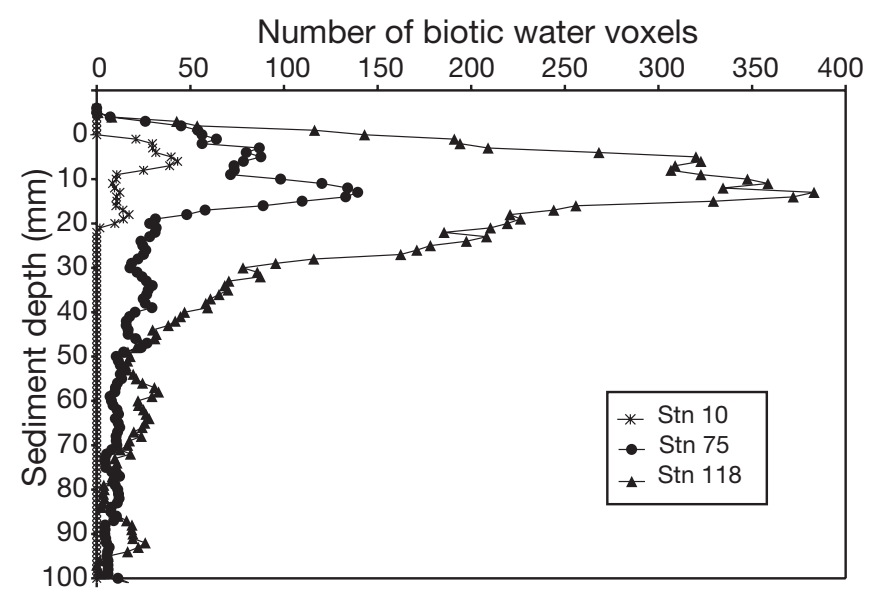

Fig. 6. Estimated relative volumes (number of voxels) in worm tubes and shells inhabited by animals (biotic water; $\mathrm{CT}=0$ to 350) vs. sediment depth at Stns 10, 75 and 118. Station numbers as in Fig. 1

scanned in horizontal position, we recommend using the CR technique rather than the PV method. The photographs of the living bivalves and tube worms, stones, and unoccupied shells and tubes sieved from the sediment cores were useful to ground truth the potential locations of these objects found within the CT core images.

\section{CT analysis of biogenic structures}

The CT technique for analyzing biogenic structures was previously applied by Perez et al. (1999) in Rhode Island, USA, and in 3 studies in the Gulf of St Lawrence, Canada (Mermillod-Blondin et al. 2003, Michaud et al. 2003, Dufour et al. 2005). In total, 17 samples were scanned for CT analysis in these studies. The Canadian studies focused on the space occupied by biogenic structures versus depth. In MermillodBlondin et al. (2003) and Michaud et al. (2003), the space occupation was between 21 and $44 \%$, being greatest in the top sediment and declining with depth. The space occupied by benthic structures calculated in these studies was based upon a generalized approach using differences of tomographic intensity between benthic structures and the surrounding sediments. This technique is different to the methods used in the present study to calculate biovolume, where direct measurement of the space occupied by macrobenthic structures $(>1 \mathrm{~mm})$ was made, and the volume of recent tubes was separated from that of relic tubes.

The space occupation at Stns 75 and 118 had previously been analysed in sediment samples from 1998 to 1999 by manually sectioning sediment cores, taking a 
picture of the surface of each slice, and then digitally measuring the biogenic structures in each sediment section (Rosenberg \& Ringdahl 2005). Also in that study, the measured volumes were greatest at the surface and gradually declined with depth. However, at Stn 118, where the benthic fauna at that time were beginning to re-colonise the previously (1997) defaunated sediment, such a pattern was not found. Instead, the volume of polychaete tubes was greatest deeper in the sediment at around 7 to $14 \mathrm{~cm}$ (Rosenberg \& Ringdahl 2005). Those authors suggested that relic tubes could have caused this increase in volume, as relic tubes mainly of Melinna cristata were photographed in situ in 1997 by using a sediment profile camera at this station (Nilsson \& Rosenberg 2000). Bioturbation, and particularly horizontal bulldozing by sea urchins, such as Echinocardium spp., is likely to destroy or disconnect burrows. For example, at Stn 118 during the early phase of re-colonisation, bulldozing sea urchins were abundant (Rosenberg \& Ringdahl 2005), which may have reduced the number of burrows found in that study. Polychaete tubes probably remain intact for longer periods despite the presence of sea urchins; they have thicker walls and some can be bent without being broken.

The benthic species at Stn 10 were found close to the SWI, whereas both Stns 75 and 118 had living tube building worms down to $100 \mathrm{~mm}$ and bivalves (e.g. Thyasira equalis) down to even greater depths. Recently, Dufour \& Felbeck (2003) reported that at least 3 species of Thyasira, all present in the Gullmarsfjord, made extended burrows with the foot in the sediment to supply hosted sulphur-oxidizing bacteria with energy.

The volume of biotic water (Fig. 6) in the sediment showed the following station sequence $118>75>10$, i.e. the more and/or larger animals (predominantly tube worms) at Stn 118 produced the largest volume, and Stn 10, which had the fewest species, had the smallest volume. The majority of the biotic water at Stn 75 was located less than $200 \mathrm{~mm}$ below the SWI (Fig. 5), and a few dense tubes were also found at deeper depths, some of which did not connect to the SWI. Stn 118 contained a large number of dense tubes above and below the SWI, and relic tubes throughout all depths of the core (Fig. 5). Some tubes at Stn 118, e.g. of large terebellids, may have connected to the SWI outside the core and were therefore regarded as relic tubes. Stn 10 appeared to have much more gas and denser sediments of hard clay below $\sim 70 \mathrm{~mm}$ than the other stations (Fig. 3). All tubes were found below $\sim 100 \mathrm{~mm}$ depth at this station, and were considered relic tubes. Thus, this station seems to have harboured a richer fauna at some earlier stage.

In the present study, techniques were developed to distinguish relic tubes from recent tubes (Fig. 4).
Michaud et al. (2003) also found relic burrows in their images, but they were not separated from recent burrows in the analysis. It is evident that the inhabited tubes made of clay and polysaccharides are very dense as they appear in the same images in which CT number for shells was used (Fig. 5). It may be an advantage to have dense and perhaps impermeable tubes deeper down in sediment, where the $\mathrm{H}_{2} \mathrm{~S}$ content may be higher. Burrow linings can also have a higher density than the surrounding sediment (Dufour et al. 2005). Artificial tube walls formed by Melinna cristata from glass beads were, however, found to only reduce the diffusion of inorganic solutes to a minor degree (Hannides et al. 2005). Aller (1983) showed that tube and burrow linings of 8 marine invertebrates acted as barriers to diffusion. Fenchel (1996), however, found that the thin mucus lining of burrow walls of the polychaete Nereis diversicolor did not provide any measurable diffusion barrier for oxygen. So far, no studies have shown whether intact Melinna cristata tubes and the lining act as a barrier to some or most solutes in the sediment. The initial high density of tube material found in the present study is most probably also the reason why relic tubes can persist in the sediment for long periods. The density of the material of relic tubes is, however, gradually reduced, and the tubes deeper in the sediment appeared to be disintegrated.

Munksby et al. (2002) concluded that passive irrigation depends on the hydrologic conductivity of the sediment, the flow velocity of the overlaying water, the geometry of the tube and its relative position in the sediment. The authors found that large numbers of relic tubes (45 to $87 \%$ of the total) of Spiochaetopterus bergensis in the deeper $(695 \mathrm{~m})$ parts of the Skagerrak had profound effects on the biogeochemistry of the otherwise impermeable sediment. Thus, passive irrigation may occur in relic tubes connecting to the SWI. In contrast, relic tubes that are not connected to the SWI probably have little impact on the pore water solute distribution (Aller 1984).

The assessment of biogenic structures during the early colonization phase in 1998 to 1999, i.e. about 1 yr after the hypoxia, revealed few biogenic structures at Stn 118 although many species were present (Rosenberg \& Ringdahl 2005). In the present study 5 yr later, the volume of biogenic structures exceeded even that of Stn 75. Thus, the presence of relic tubes does not seem to hamper establishment of new ones; rather they co-occur at the same spot. The organic matter accumulating at Stn 118 could have stimulated increased aerobic mineralization through increased sediment reworking and bioirrigation subsequent to re-oxygenation of the bottom water (Hansen \& Blackburn 1991, Kristensen et al. 1995). 


\section{CT compared to other techniques}

A number of other techniques have been developed and used for visualizing and analysing biogenic structures in sediments. X-radiography has been used in a number of studies for analysing biogenic structures and bioturbation in marine sediments (e.g. Gerino et al. 1999, Rhoads \& Boyer 1982). This technique has also been developed into digital X-radiography (Scophix) where the image quality can be enhanced (Migeon et al. 1999). The drawbacks of these techniques are that only sediments of a thickness of a few centimetres can be analyzed in $2 \mathrm{D}$, and that estimates of space occupation by biogenic structures has to be made from successive slabs, which is time consuming (Dufour et al. 2005). Resin casts have been used in a number of studies to visualize the architecture of burrow structures of, e.g. thallassinidean crustaceans (Astall et al. 1997) and larger polychaetes (Davey 1994). This technique can be used in situ intertidally, or subtidally in shallow waters by diving. The disadvantages of this method are that the observer has to locate the burrow or tube openings at the SWI to introduce the resin, and small structures would not be included in the analysis. Another technique is to slice deep-frozen sediment cores horizontally in thin sections and to digitally analyze and reconstruct the biogenic structures (Fossing et al. 1995, Rosenberg \& Ringdahl 2005). This method seems to give accurate measurements but is time consuming.

The SPI technique was introduced by Rhoads \& Cande (1971) and has since been used in a number of studies for 2D in situ analysis of sediment properties, biogenic structures and successional stages of benthic communities (e.g. Rhoads \& Germano 1986, Nilsson \& Rosenberg 2000). SPI is cost-effective and most useful for quick surveillance of the benthic environmental quality. SPI has one advantage over CT scanning in that SPI allows the analysis of the sediment redox conditions and their relationship to biogenic structures, influenced by bioirrigation activity. SPI was used for this purpose in the Koljöfjord where Stn 10 is located (Rosenberg et al. 2001). The results in the present and the earlier study (Rosenberg et al. 2001) confirmed that the fauna was distributed close to the SWI and that oxidized sediment was present only at the very top sediment at stations in shallow waters. However, SPI only allows analysis of structures close to the face plate of the prism, as objects at some distance will be out of focus.

One advantage of CT scanning is that structures in rather large volumes of sediment can be visualized in both $2 \mathrm{D}$ and $3 \mathrm{D}$, and that the density of all voxels in the sediment can be analyzed. Another advantage is that CT can be used to quantify marine macrofaunal activ- ity pattern in sediments with respect to 2 biologically related parameters: the volume of the structures that macrofauna create (biovolume) and the modifications they contribute to the SXA. However, in the present study, the separate analysis of recent and relic tubes was time consuming, as was the analysis of volumes of tubes and burrows. However, since medical CT scanners are available at most hospitals, these CT techniques could be applied to scientific studies throughout most of the world. A challenging development of research could be to measure the bioturbation and ventilation of different species, group them into functional groups, and correlate their biogenic structures and activity patterns with mineralization rates, fluxes of nutrients, and oxygen consumption. Refinement of CT software for easier and quicker image analysis will also improve such quantification processes.

Acknowledgements. We sincerely thank the personnel of Lysekil Hospital for use of the medical scanner and for the professional assistance of the technicians. We thank Ms. R. Johnson (US Environmental Protection Agency) for statistical support and Professor G. Desrosiers for the inspiration to use CT.

\section{LITERATURE CITED}

Aller RC (1983) The importance of the diffusive permeability of animal burrow linings in determining marine sediment chemistry. J Mar Res 41:299-322

Aller RC (1984) The importance of relict burrow structures and burrow irrigation in controlling sedimentary solute distributions. Geochim Cosmochim Acta 48:1929-1934

Astall CM, Taylor AC, Atkinson RJA (1997) Behavioural and physiological implications of a burrow-dwelling lifecycle for two species of upogebiid mud-shrimp (Crustacea: Thalassinidea). Estuar Coast Shelf Sci 44:155-168

Davey JT (1994) The architecture of the burrow of Nereis diversicolor and its quantification in relation to sedimentwater exchange. J Exp Mar Biol Ecol 179:115-129

Dufour SC, Felbeck H (2003) Sulphide mining by the superextensile foot of symbiotic thyasirid bivalves. Nature 426 : $65-67$

Dufour SC, Desrosiers G, Long B, Lajeunesse P, Gagnoud M, Labrie J, Archamboult P, Stora G (2005) A new method for three-dimensional visualization and quantification of biogenic structures in aquatic sediments using axial tomodensitometry. Limnol Oceanogr Methods 3:372-380

Emmerson MC, Solan M, Emes C, Paterson D, Raffaelli DG (2001) Consistent patterns and idiosyncratic effects of biodiversity in marine ecosystems. Nature 411:73-77

Fenchel T (1996) Worm burrows and oxic microniches in marine sediments. 1. Spatial and temporal scales. Mar Biol 127: 289-295

Forster S (1996) Spatial and temporal distribution of oxidation events occurring below the sediment-water interface. PSZN I: Mar Ecol 17:309-319

Fossing H, Gallardo VA, Jørgensen BB, Hüttel M and 11 others (1995) Concentration and transport of nitrate by matforming sulphur bacterium Thioploca. Nature 374:713-715

François F, Gerino M, Stora G, Durbec JP, Poggiale JC (2002) Functional approach to sediment reworking by galleryforming macrobenthic organisms: modeling and applica- 
tion with the polychaete Nereis diversicolor. Mar Ecol Prog Ser 229:127-136

Furukawa Y, Bentley SJ, Lavoie DL (2001) Bioirrigation modeling in experimental benthic mesocosms. J Mar Res 59: $417-452$

Gerino M, Stora G, Weber O (1999) Evidence of bioturbation in the Cap-Ferret Canyon in the deep northeastern Atlantic. Deep-Sea Res II 46:2289-2307

Gerino M, Stora G, Francois-Carcaillet F, Gilbert F, Poggiale JC, Mermillod-Blondin F, Desrosiers G, Vervier P (2003) Macro-invertebrate functional groups in freshwater and marine sediments: a common mechanistic classification. Vie Milieu 53:221-231

Grémare A, Duchêne JC, Rosenberg R, David E, Desmalades M (2004) Feeding behaviour and functional response of Abra ovata and A. nitida compared by image analysis. Mar Ecol Prog Ser 267:195-208

Hannides AK, Dunn SM, Aller RC (2005) Diffusion of organic and inorganic solutes through macrofaunal mucus secretions and tube linings in marine sediments. J Mar Res 63: 967-981

Hansen LS, Blackburn TH (1991) Aerobic and anaerobic mineralization of organic material in marine sediment microcosms. Mar Ecol Prog Ser 75:283-291

Josefson AB, Forbes TL, Rosenberg R (2002) Fate of phytodetritus in marine sediments: functional importance of macrofaunal community. Mar Ecol Prog Ser 230:71-85

Karlson K, Hulth S, Ringdahl K, Rosenberg R (2005) Experimental recolonisation of Baltic Sea reduced sediments: survival of benthic macrofauna and effects of nutrient cycling. Mar Ecol Prog Ser 294:35-49

Kristensen E, Ahmed SI, Devol AH (1995) Aerobic and anaerobic decomposition of organic matter in marine sediments: Which is fastest? Limnol Oceanogr 40:1430-1437

Ligier Y, Ratib O, Logean M, Girard C (1994) Osiris: A medical image manipulation system. MD Computing Journal 4: 212-218

Mermillod-Blondin F, Marie S, Desrosiers G, Long B, deMontety L, Michaud E, Stora G (2003) Assessment of the spatial variability of intertidal benthic communities by axial tomodensitometry: importance of fine-scale heterogeneity. J Exp Mar Biol Ecol 287:193-208

Mermillod-Blondin F, Rosenberg R, Francois-Carcaillet F, Norling K, Mauclaire L (2004) Influence of bioturbation by three benthic infaunal species on microbial communities and biogeochemical processes in marine sediment. Aquat Microb Ecol 36:271-284

Mermillod-Blondin F, Francois-Carcaillet F, Rosenberg R (2005) Biodiversity of benthic invertebrates and organic matter processing in shallow marine sediments: an experimental study. J Exp Mar Biol Ecol 315:187-209

Michaud E, Desrosiers G, Long B, deMontety L and 5 others (2003) Use of axial tomography to follow temporal changes of benthic communities in an unstable sedimentary environment (Baie des Ha! Ha!, Saguenay Fjord). J Exp Mar Biol Ecol 285-286:265-282

Migeon S, Weber O, Faugers JC, Saint-Paul J (1999) SCOPIX: a newX-ray imaging system for core analysis. Geo Mar Lett 18:251-255

Editorial responsibility: Otto Kinne (Editor-in-Chief), Oldendorf/Luhe, Germany
Munksby N, Benthien M, Glud RN (2002) Flow-induced flushing of relict tube structures in the central Skagerrak (Norway). Mar Biol 141:939-945

Nilsson HC, Rosenberg R (2000) Succession in marine benthic habitats and fauna in response to oxygen deficiency: analysed by sediment profile-imaging and by grab samples. Mar Ecol Prog Ser 197:139-149

Pearson TH (2001) Functional group ecology in soft-sediment marine benthos: the role of bioturbation. Oceanogr Mar Biol Annu Rev 39:233-267

Pearson TH, Rosenberg R (1987) Feast and famine: structuring factors in marine benthic communities. In: Gee JHR, Giller PS (eds) 27th Symposium of the British Ecological Society Aberystwyth 1986. Blackwell Scientific Publications, Oxford, p 373-395

Perez KT, Davey EW, Moore RH, Burn PR, Rosol MS, Cardin JA, Johnson RL, Kopans DN (1999) Application of computer-aided tomography (CT) to the study of estuarine benthic communities. Ecol Appl 9:1050-1058

Rhoads DC, Boyer LF (1982) The effects of marine benthos on physical properties of sediments. A successional perspective. In: McCall PL, Tevesz MJS (eds) Animal-sediment relations, Vol 2. Plenum Press, New York, p 3-52

Rhoads DC, Cande S (1971) Sediment profile camera for in situ study of organism-sedimment relations. Limnol Oceanogr 16:110-114

Rhoads DC, Germano JD (1986) Interpreting long-term changes in benthic community structure: a new protocol. Hydrobiologia 142:291-308

Riisgård HU, Larsen PS (2005) Water pumping and analysis of flow in burrowing zoobenthos: an overview. Aquat Ecol 39: $237-258$

Rosenberg R, Ringdahl K (2005) Quantification of biogenic 3-D structures in marine sediments. J Exp Mar Biol Ecol 326: $67-76$

Rosenberg R, Nilsson HC, Diaz RJ (2001) Response of benthic fauna and changing sediment redox profiles over a hypoxic gradient. Estuar Coast Shelf Sci 53:343-350

Rosenberg R, Agrenius S, Hellman B, Nilsson HC, Norling K (2002) Recovery of benthic habitats and fauna in a Swedish fjord following improved oxygen conditions. Mar Ecol Prog Ser 234:43-53

Schaffner LC, Dellapenna TM, Hinchey EK, Friedrichs CT, Thompson Neubauer M, Smith ME, Kuehl SA (2001) Physical energy regimes, seabed dynamics, and organism-sediment interactions along an estuarine gradient. In: Aller JY, Woodin SA, Aller RC (eds) Organism-sediment interactions. Belle W. Baruch Institute for Marine Biology and Coastal Research, Columbia, SC, p 159-179

Schulz HN, Jørgensen BB, Fossing HA, Ramsing NB (1996) Community structure of filamentous, sheat-building sulfur bacteria, Thioploca spp., off the coast of Chile. Appl Environ Microbiol 62:1855-1862

Solan M, Wigham BD, Hudson IR, Kennedy R, Coulon $\mathrm{CH}$, Norling $K_{1}$ Nilsson HC, Rosenberg R (2004) In situ quantification of bioturbation using time-lapse fluorescent sediment profile imaging (f-SPI), luminophore tracers and model simulation. Mar Ecol Prog Ser 271:1-12

Submitted: February 17, 2006; Accepted: June 15, 2006 Proofs received from author(s): January 30, 2007 